\title{
The origin of lamproites revisited: Mediterranean perspective
}

\author{
Dejan Prelević, Stephen F. Foley \\ Institute of Geological Sciences, University of Mainz, Becherweg 21, D-55099 Mainz, Germany
}

Since recognition of lamproites as important diamond carrier in the 1970 s, their origin repeatedly attracted many researchers. They are mantle-derived volcanics characterized by severe enrichment in incompatible trace-elements combined with variable and extreme radiogenic isotope compositions. General agreement exists that a normal four-phase peridotitic mantle cannot represent their source, because a K-rich hydrous mineral, in most models phlogopite, is required. The origin of the metasomatism which enriched their mantle source is, however, a confusing issue, as lamproites typically have a very "ancient" isotopic signature which cannot always be related to known tectonic events: it is either an ancient event with a metasomatic component derived from the convecting mantle, or is a more recent introduction of an already aged metasomatic component. This view, together with different trace element signatures, serves ultimately for a general distinction between anorogenic and orogenic lamproites (Fig. 1).

\section{Orogenic vs anorogenic lamproites}

Orogenic lamproites share all geochemical characteristics with magmas generated in subductionrelated (orogenic) tectonic settings, with enrichment of Large Ion Lithophile (LIL) over High Field Strength (HFS) elements, the presence of $\mathrm{T}(\mathrm{a}) \mathrm{N}(\mathrm{b}) \mathrm{T}(\mathrm{i})$ troughs and $\mathrm{Pb}$ peaks. The anorogenic lamproites show enrichment of High Field Strength (HFS) elements over Large Ion Lithophile (LIL) elements, and TNT anomaly disappears.

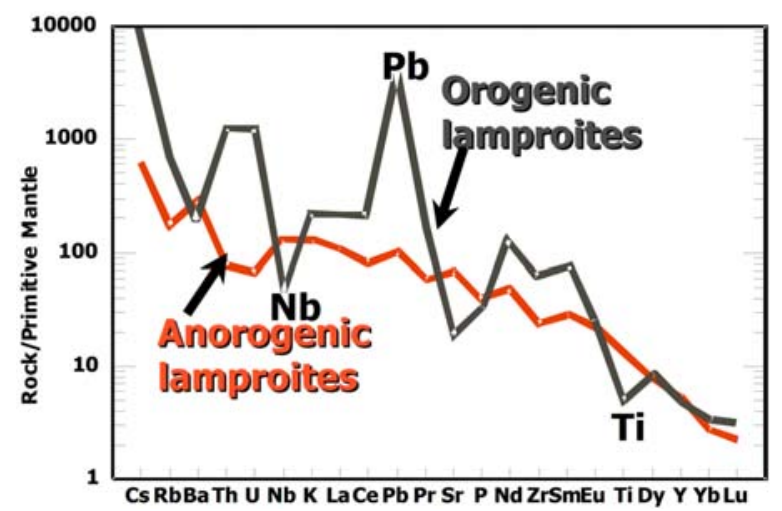

Fig. 1 Orogenic vs anorogenic lamproites: trace element signature.

\section{Mediterranean Tertiary volcanism}

Lamproitic volcanism is widespread in the Mediterranean area (Figure 2) (Prelević et al., 2007, and references therein). It presents an integral part of postcollisional volcanism within the Alpine-Himalayan belt, which took place between the late EoceneOligocene and the present day. Given their primitive character, lamproites are very often interpreted as potential candidates for parental melts of more voluminous postcollisional volcanics like trachybasalts, shoshonites and leucitites (PRELEVIĆ et al., 2004). Coevally with postcollisional volcanism, CircumMediterranean anorogenic Na-alkaline Cenozoic igneous volcanism (Lustrino \& Wilson, 2007) apparently of sublithospheric mantle origin occurs all over Mediterranean. Na-rich alkaline volcanism has been reported within the Iberian Hercynian Massif, Apennine Peninsula, Serbia and Turkey.

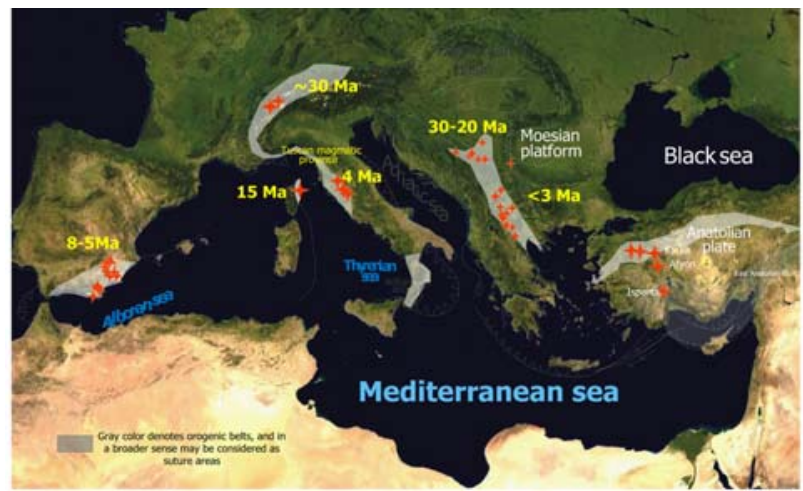

Fig. 2 Distribution of Mediterranean lamproites with their ages.

\section{Mediterranean lamproites}

Most of the Mediterranean lamproites share common geochemical features with their worldwide orogenic counterparts (Fig 3). Their isotopic signatures though, imply derivation from melts with three mantle components involved in their origin, characterized by contrasting geochemical features which appear in ${ }^{206} \mathrm{~Pb} /{ }^{204} \mathrm{~Pb},{ }^{87} \mathrm{Sr} /{ }^{86} \mathrm{Sr}$ and ${ }^{143} \mathrm{Nd} /{ }^{144} \mathrm{Nd}$ space (PRELEVIĆ et al., 2008): (1) a mantle source contaminated by crustal material, giving rise to crust-like trace element patterns and radiogenic isotope systematics, (2) an ultra-depleted mantle component derived from oceanictype mantle accreted to older lithosphere during Mesozoic collisional processes (Prelević \& Foley, 2007), isotopically similar to Depleted (MORB) Mantle (Zindler \& Hart, 1986) and (3) a component 
originating from the convecting mantle. The presence of so many components demand multistage preconditioning of the lamproite mantle source, involving an episode of extreme depletion, followed by involvement of terrigenous sediments, and finally interaction with melts originating from the convecting mantle, some of which are probably carbonatitic (PRELEVIĆ et al., 2008).

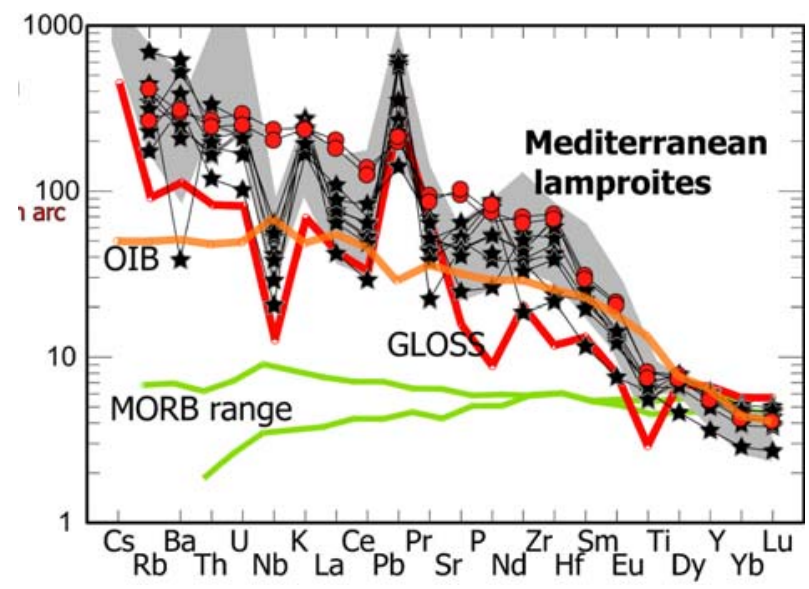

Fig. 3 Trace element signature of Mediterranean lamproites. Black stars denote Turkish "orogenic", and red circles "anorogenic" lamproites.

\section{Anorogenic lamproites in orogenic setting: Turkey}

Although the majority of Mediterranean lamproites have an orogenic affinity, with radiogenic ${ }^{87} \mathrm{Sr} /{ }^{86} \mathrm{Sr}$, ${ }^{207} \mathrm{~Pb} /{ }^{204} \mathrm{~Pb}$, unradiogenic ${ }^{143} \mathrm{Nd} /{ }^{144} \mathrm{Nd}$ and ${ }^{206} \mathrm{~Pb} /{ }^{204} \mathrm{~Pb}$, and high LILE/HFSE ratios, the lamproites from few localities in Turkey exhibit geochemical features characteristic for anorogenic lamproites and generally resemble melts derived from convecting mantle. They have lower silica and higher $\mathrm{CaO}$ contents, with unradiogenic ${ }^{87} \mathrm{Sr} /{ }^{86} \mathrm{Sr},{ }^{207} \mathrm{~Pb} /{ }^{204} \mathrm{~Pb}$, and radiogenic ${ }^{143} \mathrm{Nd} /{ }^{144} \mathrm{Nd}$ and ${ }^{206} \mathrm{~Pb} /{ }^{204} \mathrm{~Pb}$, coupled with rather smooth incompatible trace element pattern with low LILE/HFSE ratios, lower $\mathrm{Pb}$ peak and high concentrations of $\mathrm{Nb}$ and Ti (Figs. 3 and 4).

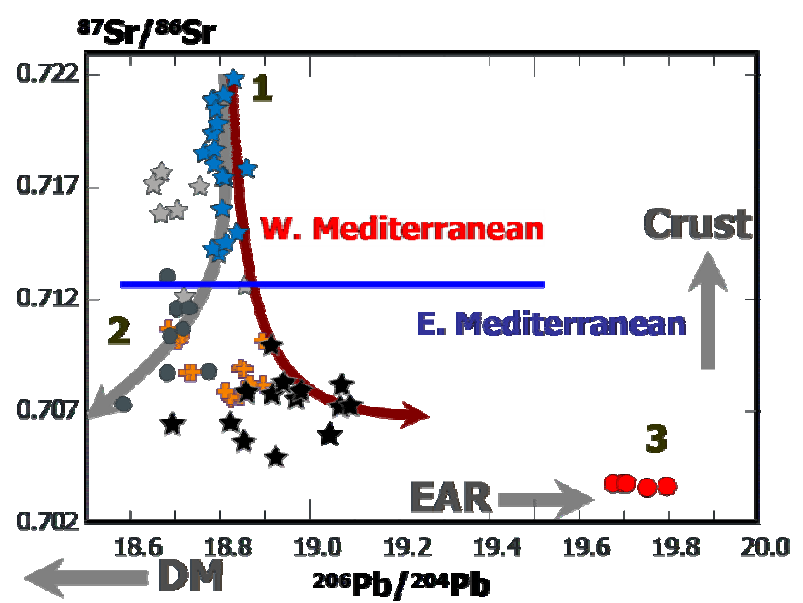

Fig. $4 \mathrm{~Pb}$ vs $\mathrm{Sr}$ isotopes for Mediterranean lamproites: three mantle components.
Still, their $\mathrm{K}_{2} \mathrm{O}$ contents is similar to that of anorogenic lamproites, and is near-constant (6.5 \pm 2 wt.\%) indicating buffering by residual phlogopite during melt segregation. This is because $\mathrm{K}$ is a stoichiometric component in phlogopite and the $\mathrm{K}_{2} \mathrm{O}$ contents in the melt will be buffered as long as this phase is residual. The identification of residual phlogopite in the source of Mediterranean lamproites, including Turkish anorogenic ones, has important implications for the location of the magma sources. The phase relationships show that phlogopite is not stable in the asthenospheric upper mantle nor in thermal plumes. In both cases temperature is the limiting parameter rather than pressure. Phlogopite is stable in the cold continental and oceanic lithospheric mantle.

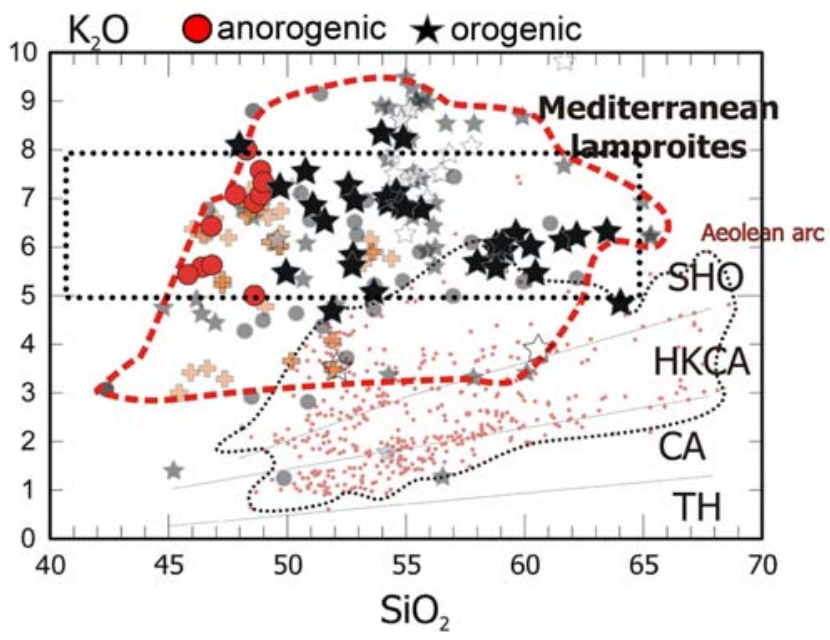

Fig. $5 \mathrm{SiO}_{2}$ vs $\mathrm{K}_{2} \mathrm{O}$ variation for Mediterranean lamproites. Note constantly high potassium contents in both "types" of Turkish lamproites.

\section{Geodynamic scenario and petrogenetic model}

General geodynamic environment during which Turkish volcanism has been triggered, is clearly postcollisional and extensional. It resulted after the collision of the Sakarya and Tauride continental blocks in the early Eocene (OKAY et al., 1996). It was proposed that during poscollisional orogenic collapse, the exhumation of several metamorphic core complexes has taken place. Lamproitic magmatism spatially surrounds the largest of them, the Menderes core complex (Figure 6), and they temporally track all extensional episodes recorded in its exhumation (Figure 7): the oldest lamproites occur in the 23-20 Ma coevally with the beginning of extensional deformation in the northern Menderes Core Complex; the major episodes of the tectonic exhumation of middle-crustal rocks in the central Menderes Massif is also the time of the major lamproitic volcanism in several locations surrounding Menderes; finally, the youngest southernmost lamproites occur contemporary with the last extensional episode recorded in Menderes as well, around $5 \mathrm{My}$, and correlates with initiation of N. Anatolian fault. 


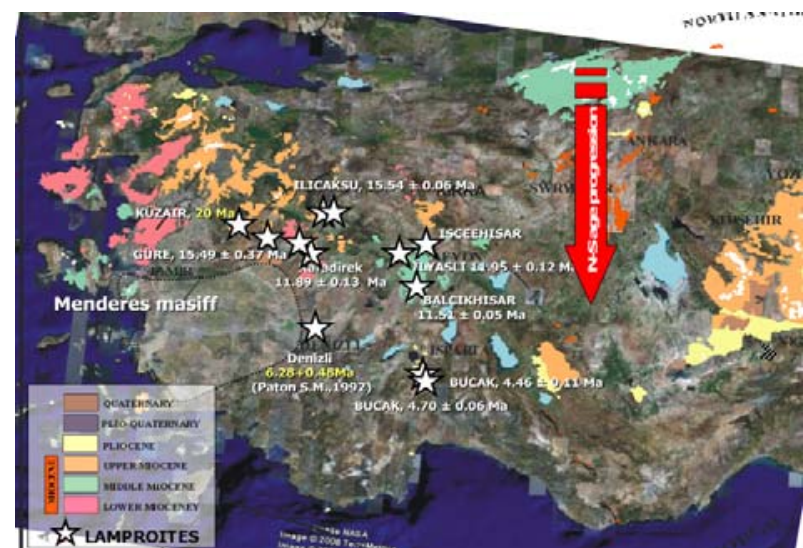

Fig. 6 Time and space distribution of Turkish lamproites, together with other types of volcanism.

The extensional episodes recorded within Menderes core complex most probably represent overall lithosphere response to the poscollisional isostatic requilibration and subsurface compensation.

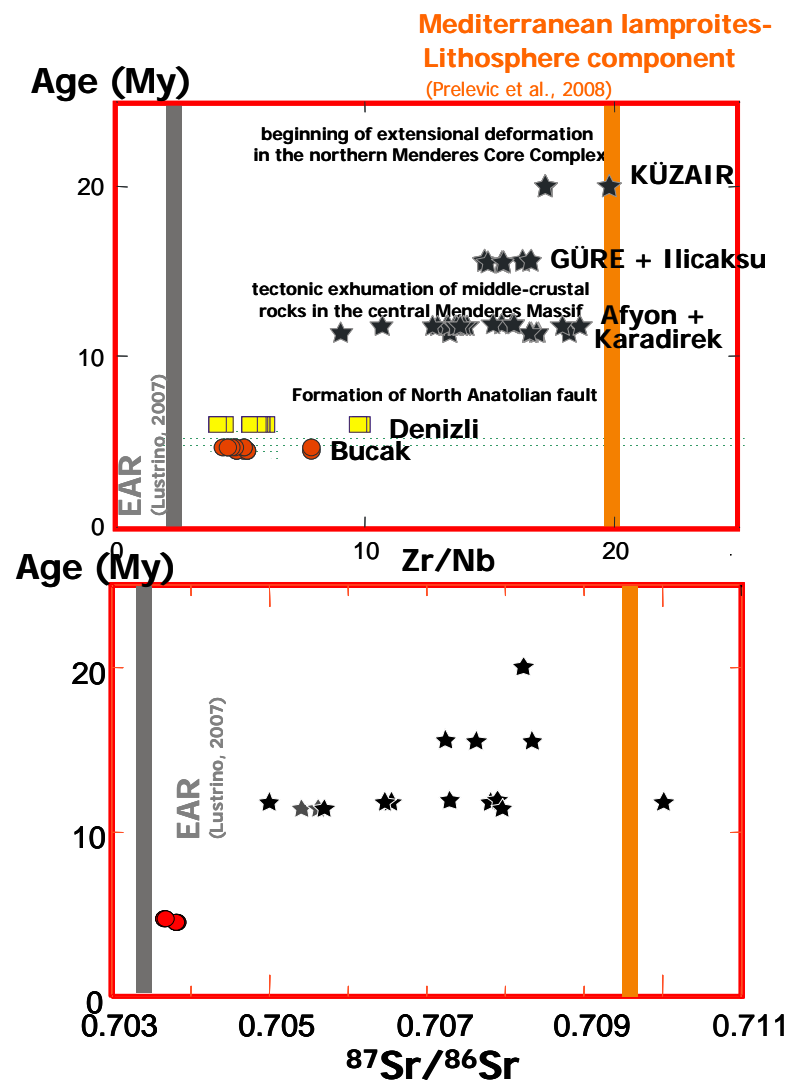

Fig. $7 \mathrm{Zr} / \mathrm{Nb}$ and ${ }^{87} \mathrm{Sr} /{ }^{86} \mathrm{Sr}$ vs. age for Turkish lamproites illustrating pronounced lithosphereasthenosphere interaction with time. Also three major extensional episodes recognized during the exhumation of Menderes core complex are denoted.

When we put our geochemical data in the time-frame, we recognize a progressive southward youngering of lamproitic volcanism coupled with an increasing intensity of asthenosphere-lithosphere interaction. Our geochemical together with age data imply that in Miocene (20 Ma) we have first lamproitic volcanism which could be regarded as pure crustaly- metasomatized lithosphere-derived melts originated at the beginning of the lithosphere delamination. With age progression, we have advanced delamination and denudation of heterogeneously metasomatized lithospheric mantle which enabled more pronounced asthenosphere-lithosphere interaction, culminating in Pliocene, when "anorogenic" lamproites have erupted. According to our interpretation, whole lamproitic volcanism, originated by the melting of the lithospheric mantle, which underwent intense astenospherisation through time. We propose that lamproitic volcanism illustrate the reaction of the lithospheric mantle, including its delamination, with increase of intensity of lithosphere-asthenosphere interaction. Our petrogenetic model has implications for the interaction between sublithospheric mantle and the SCLM and melt generation in the SCLM.

\section{References}

Lustrino, M. \& Wilson, M. (2007). The circumMediterranean anorogenic Cenozoic igneous province. Earth-Science Reviews 81, 1.

Okay, A. I., Satir, M., Maluski, H., Siyako, M., Monie, P., Metzger, R. \& Akyüz, S. (1996). Paleo- and NeoTethyan events in northwest Turkey: Geological and geochronological constraints. In: Yin, A., and Harrison, M.T. (ed.) Tectonics of Asia: Cambridge, Cambridge University Press, 420-441.

Prelević, D. \& Foley, S. F. (2007). Accretion of arc-oceanic lithospheric mantle in the Mediterranean: evidence from extremely high-Mg olivines and Cr-rich spinel inclusions from lamproites. Earth and Planetary Science Letters 256, 120-135.

Prelević, D., Foley, S. F. \& Cvetković, V. (2007). A review of petrogenesis of Mediterranean Tertiary lamproites: a perspective from the Serbian ultrapotassic province. In: L. Beccaluva, G. Bianchini \& Wilson, M. (eds.) Cenozoic Volcanism in the Mediterranean Area: Geological Society of America Special Paper 418, 113-129.

Prelević, D., Foley, S. F., Cvetković, V. \& Romer, R. L. (2004). Origin of Minette by Mixing of Lamproite and Dacite Magmas in Veliki Majdan, Serbia. Journal of Petrology 45, 759-792.

Prelević, D., Foley, S. F., Romer, R. \& Conticelli, S. (2008). Mediterranean Tertiary lamproites derived from multiple source components in postcollisional geodynamics. Geochimica et Cosmochimica Acta 72, 2125-2156.

Zindler, A. \& Hart, S. (1986). Chemical geodynamics. Annual Review of Earth and Planetary Sciences 14, 493-571. 